\title{
A kiegészítő melléklet információtartalmának összehasonlítása az információ-technológiai szolgáltatás és a sporttevékenység körében
}

\section{Comparison of the Information Content of the Notes on the Accounts between Information Technology Services and Sports Activities}

\author{
D. KEREZSI ${ }^{1}$
}

1Debreceni Egyetem, Gazdaságtudományi Kar, Számviteli és Pénzügyi Intézet, kerezsi.dora@econ.unideb.hu

Absztrakt. . Napjainkban a számviteli beszámoló az egyik fontos információs forrás a vállalatok közötti gazdasági kapcsolatokban. Két alapvető részéből, a mérlegből és az eredmény-kimutatásból, azok aggregált jellegéből adódóan, akkor lehet a szükséges információhoz jutni, ha a harmadik része, a kiegészítő melléklet tartalmazza azokat az információkat, amelyek hozzájárulnak a beszámoló jobb értelmezéséhez. Ezen túl a kiegészítő mellékletnek segítenie kell a megbízható és valós összkép jobb bemutatását. A kiegészítő mellékletben a közlendő információk mélysége, részletezettsége nincs konkrétan megfogalmazva, ezért ezek szakmai mérlegelése az adott vállalkozásra van bízva. Alapvető célkitüzésem, hogy bemutassam milyen hasonlóságok és különbségek figyelhetők meg az információtechnológiai szolgáltatást végző és a sporttevékenységet folytató vállalkozások kiegészítő mellékleteinek információtartalmában. Szövegbányászat segítségével azt vizsgáltam, hogy milyen mértékben felelnek meg a törvényi elöírásoknak.

\begin{abstract}
Annual accounting statements are an important source of information within business relations amongst companies. However, it should be noted that due to their aggregate nature, the necessary information and through that the necessary knowledge can only be obtained from the two fundamental parts of the annual statements (balance sheet and profit and loss account) if the notes on the account contains the information that contributes to the more comprehensive interpretation of the other part of the annual statement. Beyond that, the notes to the financial statement have to help the presentation of a reliable and realistic overall image. In the notes to the financial statement, depth and detail of the disclosed information are not specifically stated, therefore their professional evaluation is left to the given enterprise. My basic purpose is to illustrate a comparison of the information content of the notes on the accounts between information technology services and sports activities. By means of text mining, we analyse the extent to which the notes on the accounts are in conformity with the Accounting Act.
\end{abstract}




\section{Bevezetés}

A felgyorsult világban a globális változások minden egyes gazdálkodót arra ösztönöznek, hogy megfelelő magatartást tanusítson a közvetlen és közvetett környezetük iránt. Abban az esetben, ha ezt a kérdéskört a vállalkozások gazdálkodása, működése szempontjából vizsgáljuk, a különféle törvények és szabályzatok érvényre jutásán keresztül a számviteli beszámoló formájában mutatkozik meg. Ez a beszámoló minden partner számára elérhető, nyilvános, legfőbb célja a vállalkozás helyzetének, működésének átfogó bemutatása, melyet a 2000. évi C törvény szabályoz [1]. A vállalkozás vagyoni helyzetét bemutató mérleg és a bevételekről, költségekről és ráfordításokról tájékoztató eredménykimutatás, továbbá az éves beszámoló részét képező kiegészítő melléklet a vállalat vagyoni, pénzügyi, jövedelmi helyzetéről tájékoztatja a külső érintetteket [2]. Azaz ezek biztosítják a piaci szereplők számára az elkészített beszámoló megbízható és valós összképet biztosító tájékoztatás nyújtását vagyoni helyzetéről, eszközeiről és forrásairól, az azokban bekövetkezett változásokról, pénzügyi és jövedelmezőségi helyzetéről, illetve jövőbeli terveiről [3]. Látható, hogy a számviteli beszámoló nagyon fontos információforrás lehet, viszont alapvetően a két számszerû adatokat tartalmazó része mellett a mérleg és az eredménykimutatás aggregált jellegéből adódóan akkor juthat egy szereplő kellő infomrációhoz, ha a harmadik része, a kiegészítő melléklet is tartalmazza azokat a szöveges magyarázatokat, amelyeket a törvény előír, valamint a döntséhozatallt elősegíti. Számos elemzés során mérleg és az eredménykimutatás hatékony felhasználása akadályokba ütközik egy hiányos kiegészítő melléklet mellett [4]. A kutatással célom volt feltérképezni azt, hogy két eltérő gazdasági ágazat vállalkozásainak a kiegészítő mellékletei milyen mértékben felelnek meg a számviteli törvény kötelező előírásainak.

\section{A kiegészítő melléklet szükségessége}

A megbízható és valós összkép bemutatása érdekében a számvitelről szóló 2000. évi C törvény alapján a számviteli beszámoló részeként közzétett kiegészítő mellékletbe a számszaki adatokon túl azokat a szöveges információkat és magyarázatokat kell közzétenni amelyeket a számviteli törvény előír, továbbá melyek a vagyoni pénzügyi, jövedelmezőségi helyzet bemutatásához és a vállalat múködésének megismeréséhez elengedhetetlenek egy külső piaci szereplő (befektetők, partnerek) számára, valamint melyek a mérleg és eredménykimutatás megértését szolgálják [1]. A számviteli törvény a mérleghez és eredménykimutatáshoz hasonlóan nem mutatja be a kiegészítő melléklet kötelező felépítését, nem csoportosítja a közzéteendő információkat. Annak adattartalmára vonatkozó előírásokat szerepeltet a vállalkozás működésével kapcsolatban, a mérleghez és az eredménykimutatáshoz kapcsolódóan. A törvény által kért előírások tartalmilag csoportosíthatók, a gyakorlatban az átláthatóbb kép miatt három nagyobb részre osztják a vállalkozások a kiegészítő mellékletet. Az első az általános rész, amely a beszámolóban szereplő adatok megérthetőségét segíti, a specifikus rész, amely a mérleg és az eredménykimutatás számszerű adatait részletezi és magyarázza olyan sorrendben, ahogyan azok megjelennek a mérlegben és eredménykimutatásban, végül a tájékoztató rész, amely a vállalkozás helyzetének, működésének megismerését szolgálja. 
A stratégiák és a célok megvalósításához elengedhetetlen a megfelelő finanszírozás, ezért a stratégiák és célok meghatározása előtt és közben meg kell állapítani, hogy milyen pénzügyi háttérrel rendelkezik a cég, milyen értékű befektetésre lenne szükségünk, ehhez milyen finanszírozási lehetőségeink vannak és folyamatosan figyelnünk kell arra, hogy a szükséges pénzügyi háttér biztosítva legyen a munkánk során [5]. Erre a célra egy komplex mutatószámrendszer kialakítása szükséges, melyek a számviteli nyilvántartásokból, valamint a beszámolók adataiból nyerhetők ki, mellyel mérhető a vállalatok teljesítménye [6]. A számviteli adatok, a különböző jövedelmezőségi-, hatékonysági-, és pénzügyi mutatók komplex ismerete mellett [7] egyéb információkra és ismeretekre is feltétlenül szükség van a piaci környezet feltérképezéséhez, melyet a partnervállalkozások jól elkészített kiegészítő mellékletben szereplő információk egészítenek ki [8].

Szigeti et al. (2019) tanulmányában a vállalati ökológiailábnyom-számítás kihívásaival foglalkozott a KKV-szektorban. Kutatásukban azt a javaslatot tették, hogy abban az esetben, ha a kormányzat szeretne információhoz jutni a KKV-szektor környezeti teljesítményéről, az ökológiailábnyom-számításhoz szükséges főbb inputadatok természetes mértékegységben és a korábbi évek adataival összehasonlítható módon jelenjenek meg a legalább ötfős társas vállalkozások éves (számviteli) beszámolóinak kiegészítő mellékletében. Ezen információk, valamint a kidolgozott kalkulátor segítségével meghatározhatóvá válna az egyes szektorok átlagos környezetterhelése, mely megfelelő kiindulási pontot nyújthatna a vállalkozások környezeti szempontú beruházásaihoz [9].

Az éves beszámoló részét képző kiegészítő melléklet részét képzi a cash flow kimutatás, amelynek a létjogosultsága megkérdőjelezhetetlen, ezt számos nemzetközi példa is mutatja. A cash-flow kimutatás a gazdálkodó fizetőképességét érintő kérdéseket mutatja be a pénzforgalom alakulása szempontjából, ahol a menedzsment döntéseinek a péneszközökre gyakorolt hatását láthatja számszerűsítve. A szabad pénzeszköz naprakész kimutatása elengedhetetlen gazdálkodási feltétel [10]. Külső érdekcsoportok számára többletinformációt hordozhat, mint például a vállalkozás a kötelezettségeit tudja-e teljesíteni vagy a potenciális osztalékfizetés alakulása is prognosztizálhatóvá válik. Viszont a a menedzsment igényét már nem elégíti ki teljes mértékben, melynek az oka, hogy cask évente kötelező elkészíteni, valmaint múltbeli adatokat tartalmaz. Ennek okán idővel megjelent a számviteli cash flow mellett a menedzsment célokat szolgáló cash flow. A menedzsment céloknak alárendelt cash flow-k felépítése, tartalmi elemi eltérhetnek a számviteli törvény által előírt kimutatástól, melynek legfőbb oka, hogy a gazdálkodó szervezetek működése, teljesítménye is eltérő [11].

Továbbá elmondható, hogy a mérleg és eredménykimutatás számszerű adatain túl az elemzéshez szükséges egy kellőképpen részletezett kiegészítő melléklet, melyet alátámaszt Máténé - Ritzlné (2020) kutatása, ahol a multinacionális nagyvállalatok stratégiai döntéseinek hatását vizsgálták a termelés oldali GDP alakulására vonatkozóan. Az általuk elemzett vállalkozás szervezeti változásait, nyerték ki a kiegészítő mellékletből azért, hogy be tudják azonosítani, mely divízió eladása okozhatott változást a bruttó hozzáadott értékben, valamint a kiegészítő melléklet adatait felhasználva számszerűsítették a divíziók teljesítményét folyó áron [12]. Hamar (2019) cikkében a 4. ipari forradalom hatását vizsgálta a három hazai legnagyobb távközlési, telekommunikációs vállalatra vonatkozóan, pénzügyi mutatószámok segítségével, míg Katits et al. (2019) a magyar turizmusban működő top cégek pénzügyi diagnózisával foglalkoztak a kutatásukban. Arra keresték a választ, hogy a vizsgált ágazat jövedelmező, 
miközben fizetőképes, nem eladósodott, perspektivikus a működése, valamint hatékony eszköz- és vagyongazdálkodást folytat-e, továbbá, hogyan változott a pénzügyi pozíció térkép a jövedelmezőségi és kockázati mix függvényében. Mindkét kutatáshoz szükség volt az elemzett vállalkozások kiegészítő mellékletében szereplő információk figyelembevételére ahhoz, hogy az elemzés megfelelő mélységű, részletezettségú legyen, valamint szükséges volt a kiszámított mutatók magyarázatához és az összefüggések feltárásához $[13,14]$.

\section{Anyag és módszer}

Az összehasonlításhoz magyarországi székhellyel rendelkező vállalkozások kiegészítő melléklete került a mintába, ahol az egyik a főtevékenységként 62-es TEÁOR számú Információ-technológiai szolgáltatás tevékenységet folytató vállalkozások, míg a másik a 931-es TEÁOR számú Sporttevékenységet végző vállalkozások. Az adatbázisba azok a vállalkozások kerültek, akik kettős könyvvitelt készítettek a vizsgált üzleti évre vonatkozóan. Információ-technológiai szolgáltatást végzők összesen 11476 vállalat, ebből 8858 rendelkezett kiegészítő, amiből 8226 (92,87\%) vállalat kiegészítő melléklete volt feldolgozható. Míg a sporttevékenységet végző cégek esetében összesen 1747 vállalat volt, amiből 1616 vállalat rendelkezett kiegészítő melléklettel, így összesen a sporttevékenységet végző vállalatok 92,50\%-ának a kiegészítő melléklete volt feldolgozható. Az elemzést az $\mathrm{R}$ statisztikai rendszer különböző csomagjainak a felhasználásával végeztük, ahol a szövegbányászat segítségével azt vizsgáljuk, hogy a megbízható és valós összképet biztosító kiegészítő mellékletek milyen mértékben felelnek meg a törvényi elő́rásoknak, valamint milyen hasonlóságok és különbségek fedezhetők fel két eltérő tevékenységet illetően.

\section{Az információ-technológiai szolgáltatást és sporttevékenységet végző vállalkozások kiegészítő mellékletének összehasonlító elemzése}

A információ-technológiai szolgáltatást végző 8226 vizsgált vállalkozás kiegészítő mellékletét, valamint a sporttevékenységet végző 1616 vállalkozás kiegészítő mellékleteit megvizsgáltam beszámolótípus szempontjából, melynek értékeit az 1 . ábra mutatja be. Mind a két tevékenységet végző vállalkozások többsége egyszerüsített éves beszámolót készít (78\% és 82\%), ami azt jelenti, hogy a mérlege, eredménykimutatása és kiegészítő melléklete kevésbé részletes, mint az éves beszámolót készítőknek. A számviteli törvény előírja a kötelezően közzéteendő tételeket az egyszerűsített éves beszámolót készítő vállalkozók számára, amely néhány tétellel kiegészül az éves beszámoló részeként közzétett kiegészítő mellékletében is. A több információt tartalmazó éves beszámolót készítők száma az információ-technológiai szolgáltatást végzők mindössze 9\%-a, míg a sporttevékenységet végzőknek a 10\%-a. Ezen túl mind a két tevékenységű vállalkozások kiegészítő mellékletében volt arra példa, hogy nem tették közzé a készített beszámolójuk típusát, ami kötelező része lenne annak, ezt a vizsgált cégek 13\%-a és 8\%-a hagyta figyelmen kívül. 


\section{Információ-technológiai szolgáltatás}

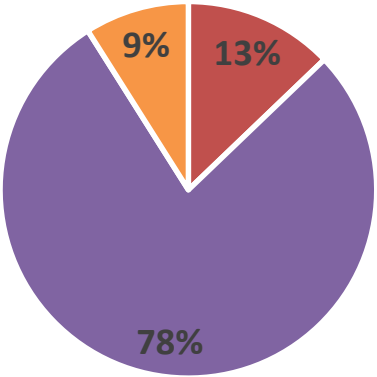

- Nem adott meg

- Egyszerúsített éves beszámoló

- Éves beszámoló
Sporttevékenység

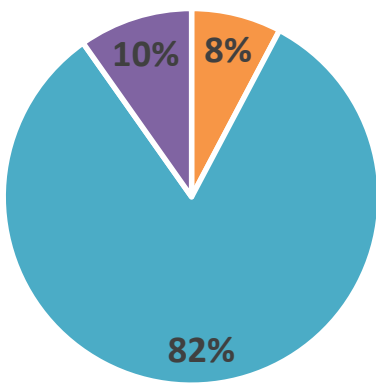

- Nem adott meg

- Egyszerűsített éves beszámoló

- Éves beszámoló

a1. ábra: Az információ-technológiai szolgáltatást és a sporttevékenységet végző vállalkozások beszámolótípus szerinti megoszlása

A beszámolótípus szerinti megoszlást követően a kétféle tevékenységi kört végző vállalkozásokat megvizsgáltam cégtípus szerint is, melynek megoszlását a 2. ábra mutatja be. Mind az informaitikai cégek, mind a sporttevékenységet végzők körében a legnagyobb arányban a korlátolt felelősségű társaságok álltak (a vizsgált vállalkozások 71\%-a és 88\%-a). Ezt az arányt követte a betéti társaságok száma, melyek a cégek 26\%-át és 12\%-át tették ki. Ezen túl az informatikai vállalatoknál előfordultak részvénytársaságok is, ez a vizsgált 8226 cég 1\%-át teszi ki, míg a mintában szerepelnek olyan vállalkozások is, amelyek nem tették közzé a kiegészítő mellékletükben a cégtípusát, ezt a 8226 vállalat mindössze 2\%-a hagyta figyelmen kívül a kötelező előírás ellenére.

Információ-technológiai szolgáltatás

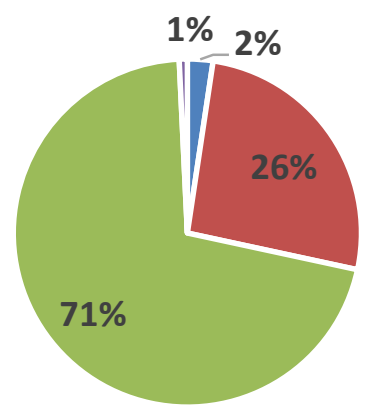

- Nem adott meg $\quad$ Bt. $\quad$ Kft. $\quad$ Rt.

\section{Sporttevékenység}

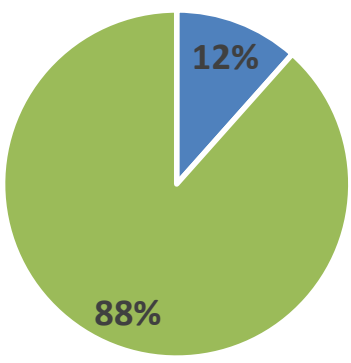

- Bt. $-\mathrm{Kft}$.

2. ábra: Az információ-technológiai szolgáltatást és a sporttevékenységet végző vállalkozások beszámolótípus szerinti megoszlása

Jelen tanulmányban néhány fontosabb információnak a kiegészítő mellékletekben történő megjelenése kerül bemutatásra az információ-technológiai szolgáltatást végző és a sporttevékenységet folytató vállalkozások összehasonlításában összevontan és beszámoló típus szerinti bontásban. Az 1 . táblázatban látható az általános rész kifejezés. A 8226 informatikai cég mindössze 33\%-a tartalmazta ezt a kifejezést, míg több mint a fele, 67\%-a nem jelenítette ezt meg. Beszámolótípus szerinti bontásban 
megvizsgálva ezt az elemzett cégek mindössze 3\%-a készít éves beszámolót, 28\%-a egyszerűsített éves beszámolót és tette közzé a kiegészítő mellékletében az általános részt. Az általános részt szerepeltető cégek 86\%-a egyszerűsítt éves beszámolót készít, míg a 9\%-uk éveset. Továbbá 5\%-uk nem szerepeltette a beszámoló típusát a megjegyzéseiben. Ezek az arányok jelentősen nem változtak a sporttevékenységet végző vállalkozások körében sem, az 1616 cég 31\%-a teszi közzé az általános részt a kiegészítő mellékletében. Az összes sportvállalkozás 56\%-a egyszerűsített éves beszámolót készít és nem jeleníti meg ezt a kifejezést. A tagolásra használt általános rész kifejezést használó cégek legnagyobb aránya 84\%-a egyszerüsített éves eszámolót készít.

\begin{tabular}{|c|c|c|c|c|}
\hline \multirow{3}{*}{ Beszámoló típus } & \multicolumn{4}{|c|}{ Általános rész } \\
\hline & \multicolumn{2}{|c|}{$\begin{array}{c}\text { Információ-technológiai } \\
\text { szolgáltatás }\end{array}$} & \multicolumn{2}{|c|}{ Sporttevékenység } \\
\hline & Nincsen & Van & Nincsen & Van \\
\hline Nem adott meg & $11 \%$ & $2 \%$ & $7 \%$ & $1 \%$ \\
\hline Egyszerűsített éves & $50 \%$ & $28 \%$ & $56 \%$ & $26 \%$ \\
\hline Éves beszámoló & $6 \%$ & $3 \%$ & $6 \%$ & $4 \%$ \\
\hline Összesen & $67 \%$ & $33 \%$ & $69 \%$ & $31 \%$ \\
\hline
\end{tabular}

1. táblázat: Az általános rész megjelenése a beszámoló típusa alapján a kiegészítő mellékletekben

Az általános rész után a specifikus rész bemutatása következik a gyakorlatban, aminek két nagyobb részét különítünk el, az egyik a mérleghez kapcsolódó kiegészítések és magyarázatok (2. táblázat), míg a másik az eredménykimutatáshoz kapcsolódó információk (3. táblázat). A 2. táblázatból látható, hogy mind a kétféle tevékenységű cégek arányai hasonlóképpen mozognak. Az általános résztől eltérően már magasabb százalékuk teszi közzé a kiegészítő mellékletben a mérleghez kapcsolódó információkat, ez a vizsgált vállalkozások felét jelenti. Legnagyobb arányban az egyszerűsített éves beszámolót készítők állnak, összes vizsgált vállalkozásnak a 43\%-a, aki bemutatta a mérleghez kapcsolódó különféle információkat. Abban az esetben, ha a közzétett kifejezés arányában vizsgáljuk, akkor elmondható, hogy azon vállalkozások, akiknek szerepel a kiegészítő mellékletükben a kifejezés kb 85\%-uk egyszerüsített éves beszámolót, és 7\%-uk éves beszámolót tett közzé.

\begin{tabular}{|c|c|c|c|c|}
\hline \multirow{3}{*}{ Beszámoló típus } & \multicolumn{4}{|c|}{ Mérleghez kapcsolódó } \\
\hline & \multicolumn{2}{|c|}{$\begin{array}{c}\text { Információ-technológiai } \\
\text { szolgáltatás }\end{array}$} & \multicolumn{2}{|c|}{ Sporttevékenység } \\
\hline & Nincsen & Van & Nincsen & Van \\
\hline Nem adott meg & $8 \%$ & $5 \%$ & $5 \%$ & $3 \%$ \\
\hline Egyszerűsített éves & $35 \%$ & $43 \%$ & $40 \%$ & $43 \%$ \\
\hline Éves beszámoló & $6 \%$ & $3 \%$ & $6 \%$ & $4 \%$ \\
\hline Összesen & $49 \%$ & $51 \%$ & $51 \%$ & $49 \%$ \\
\hline
\end{tabular}

2. táblázat: Az mérleghez kapcsolódó kifejezés megjelenése a beszámoló típusa alapján a kiegészító mellékletekben

A számviteli törvény előírja azon tételek bemutatását, kiegészítését, magyarázatát, melyek az eredménykimutatásban is szerepelnek, olyan sorrendben, ahogyan ott következnek. Így a 3. táblázatban megvizsgáltam az eredménykimutatáshoz kapcsolódó kifejezés közzétételének arányát az informatikai és sportvállalkozások körében. A mérlegtől eltérően, itt már csökkent azon cégek aránya, akik 
bemutatják ezt a kiegészítő mellékletükben (33\% és 36\%). Az informatikai cégek jelentős része 49\%-a egyszerűsített éves beszámolót készít és nem teszi közzé ezen információkat (49\%), ez igaz a sportvállalkozásokra is (52\%). Az éves beszámolót készítő informatikai cégek 20\%-a, míg a sportvállalkozások 35\%-a mutatta be ezen magyarázatokat.

\begin{tabular}{|c|c|c|c|c|}
\hline \multirow{3}{*}{ Beszámoló típus } & \multicolumn{4}{|c|}{ Eredménykimutatáshoz kapcsolódó } \\
\hline & \multicolumn{2}{|c|}{$\begin{array}{c}\text { Információ-technológiai } \\
\text { szolgáltatás }\end{array}$} & \multicolumn{2}{|c|}{ Sporttevékenység } \\
\hline & Nincsen & Van & Nincsen & Van \\
\hline Nem adott meg & $10 \%$ & $3 \%$ & $6 \%$ & $2 \%$ \\
\hline Egyszerűsített éves & $49 \%$ & $29 \%$ & $52 \%$ & $31 \%$ \\
\hline Éves beszámoló & $7 \%$ & $2 \%$ & $6 \%$ & $3 \%$ \\
\hline Összesen & $67 \%$ & $33 \%$ & $64 \%$ & $36 \%$ \\
\hline
\end{tabular}

3. táblázat: Az eredménykimutatáshoz kapcsolódó kifejezés megjelenése a beszámoló típusa alapján a kiegészító mellékletekben

A kiegészítő mellékletben be kell mutatni a sajátos tevékenységgel kapcsolatos - más jogszabályban előírt - információkat is. A kiegészítő melléklet tagolásának utolsó nagyobb része a tájékoztató rész, amelynek megjelenítését a 4. táblázat tartalmazza. Az informatikai cégek mindösszesen a 32\%-a jelenítette meg ezt a kifejezést a kiegészítő mellékletében, míg ez az arány a sportvállalkozások esetében 16\%-ra csökken. A vizsgált infomatikai cégek 51\%-a készít egyszerűsített éves beszámolót és nem használja ezt a részt a kiegészítő mellékletében, míg ez a sporttevékenységet folytatók körében 68\%-ra emelkedik. A közzétett kifejezés százalékában bemutatva pedig 7\% és 9\% készít éves, míg 84\% és $87 \%$ egyszerüsített éves beszámolót.

\begin{tabular}{|l|r|r|r|r|}
\hline \multirow{2}{*}{ Beszámoló típus } & \multicolumn{4}{|c|}{ Tájékoztató rész } \\
\cline { 2 - 5 } & \multicolumn{2}{|c|}{$\begin{array}{c}\text { Információ-technológiai } \\
\text { szolgáltatás }\end{array}$} & \multicolumn{2}{c|}{ Sporttevékenység } \\
\cline { 2 - 5 } & \multicolumn{1}{|c|}{ Nincsen } & \multicolumn{1}{|c|}{ Van } & \multicolumn{1}{c|}{ Nincsen } & \multicolumn{1}{c|}{ Van } \\
\hline Nem adott meg & $10 \%$ & $3 \%$ & $7 \%$ & $1 \%$ \\
\hline Egyszerúsített éves & $51 \%$ & $27 \%$ & $68 \%$ & $14 \%$ \\
\hline Éves beszámoló & $7 \%$ & $2 \%$ & $8 \%$ & $1 \%$ \\
\hline Összesen & $\mathbf{6 8 \%}$ & $\mathbf{3 2 \%}$ & $\mathbf{8 4 \%}$ & $\mathbf{1 6 \%}$ \\
\hline
\end{tabular}

4. táblázat: A tájékoztató rész megjelenése a beszámoló típusa alapján a kiegészítő mellékletekben

A számviteli beszámoló célja, hogy a vállalkozók működéséről, vagyoni pénzügyi és jövedelmi helyzetéről megbízható és valós összképet nyújtson a piac szereplőinek. Ennek kapcsán a törvény előírja, hogy kötelező bemutatni a vagyoni, pénzügyi és jövedelmezőségi helyzetét a cégeknek a kiegészítő mellékletükben. Arra viszont nem tér ki, hogy ezt milyen típusú mutatószámokkal kell megtenni, így ez a vállalatokra van bízva. A következőekben ezek bemutatása történik az 5., 6., 7., 8., és 9. táblázatban. A kötelező törvényi előírásoktól eltérően a valós vagyoni helyzet értékelését az információ-technológiai szolgáltatást végző 8226 vállalat mindössze 39\%-a mutatta be, amelyből 33\% egyszerüsített éves, 3\% éves beszámolót készített, szintén 3\% pedig nem tette közzé a beszámoló típusát. A sporttevékenységet végző $1616 \mathrm{db}$ vállalkozás 30\%-a tette közzé, amelyből $24 \%$ volt egyszerűsített éves beszámolót készítő, $4 \%$ éveset készítő, míg $2 \%$ nem jelenítette meg 
beszámolótípusát. Továbbá a vagyoni helyzetet bemutató vállalkozások több mint két harmada egyszerűsített éves beszámolót készített a vizsgált üzleti évben.

\begin{tabular}{|c|c|c|c|c|}
\hline \multirow{3}{*}{ Beszámoló típus } & \multicolumn{4}{|c|}{ Vagyoni helyzet } \\
\hline & \multicolumn{2}{|c|}{$\begin{array}{c}\text { Információ-technológiai } \\
\text { szolgáltatás }\end{array}$} & \multicolumn{2}{|c|}{ Sporttevékenység } \\
\hline & Nincsen & Van & Nincsen & Van \\
\hline Nem adott meg & $10 \%$ & $3 \%$ & $6 \%$ & $2 \%$ \\
\hline Egyszerűsített éves & $45 \%$ & $33 \%$ & $58 \%$ & $24 \%$ \\
\hline Éves beszámoló & $6 \%$ & $3 \%$ & $6 \%$ & $4 \%$ \\
\hline Összesen & $61 \%$ & $39 \%$ & $70 \%$ & $30 \%$ \\
\hline
\end{tabular}

5 táblázat: A vagyoni helyzet bemutatása a beszámoló típusa alapján a kiegészítő mellékletekben

A számviteli törvény elő́rásai alapján a vagyoni helyzeten belül kötelező közzétenni az eszközök és a források összetételét, a saját tőke és a kötelezettségek tételeinek alakulását, amelyet a 6. táblázat és a 7. táblázat szemléltet. Arányaiba véve közel azonos százalékuk mutatta be az eszközök összetételét és a források összetételét is a vizsgált kétféle tevékenységet végző vállalkozásoknak.

\begin{tabular}{|c|c|c|c|c|}
\hline \multirow{3}{*}{ Beszámoló típus } & \multicolumn{4}{|c|}{ Eszközök összetétele } \\
\hline & \multicolumn{2}{|c|}{$\begin{array}{c}\text { Információ-technológiai } \\
\text { szolgáltatás }\end{array}$} & \multicolumn{2}{|c|}{ Sporttevékenység } \\
\hline & Nincsen & Van & Nincsen & Van \\
\hline Nem adott meg & $12 \%$ & $1 \%$ & $7 \%$ & $1 \%$ \\
\hline Egyszerűsített éves & $71 \%$ & $7 \%$ & $75 \%$ & $8 \%$ \\
\hline Éves beszámoló & $8 \%$ & $1 \%$ & $9 \%$ & $1 \%$ \\
\hline Összesen & 91\% & 9\% & $90 \%$ & $10 \%$ \\
\hline
\end{tabular}

6. táblázat: Az eszközök összetételének bemutatása a beszámoló típusa alapján a kiegészitő mellékletekben

Mind az információ-technológiai szolgáltatást végző, mind a sportvállalkozások körülbelül 10\%-a tette közzé ezen megoszlási és dinamikus viszonyszámokat, ami azt jelenti, hogy a törvényi előírásoknak a 8226 informatikai és 1616 sportvállalkozás közel 90\%-a nem felelt meg jelen esetben. A 10\%-ból legnagyobb részük (8\%) egyszerüsített éves beszámolót készített, 1\%-uk éves beszámolót, míg szintén 1\%-uk pedig nem mutatta be a beszámolótípusát. Azon vállalatok, akik az eszközök és források összetételét bemutatták a kiegészítő mellékletükben beszámolótípus megoszlását tekintve nagyrészt egyszerüsített éves beszámolót készített (81\%).

\begin{tabular}{|c|c|c|c|c|}
\hline \multirow{3}{*}{ Beszámoló típus } & \multicolumn{4}{|c|}{ Források összetétele } \\
\hline & \multicolumn{2}{|c|}{$\begin{array}{c}\text { Információ-technológiai } \\
\text { szolgáltatás }\end{array}$} & \multicolumn{2}{|c|}{ Sporttevékenység } \\
\hline & Nincsen & Van & Nincsen & Van \\
\hline Nem adott meg & $12 \%$ & $1 \%$ & $7 \%$ & $1 \%$ \\
\hline Egyszerűsített éves & $70 \%$ & $8 \%$ & $74 \%$ & $9 \%$ \\
\hline Éves beszámoló & $8 \%$ & $1 \%$ & $9 \%$ & $1 \%$ \\
\hline Összesen & $90 \%$ & $10 \%$ & $89 \%$ & $11 \%$ \\
\hline
\end{tabular}

7. táblázat: A források összetételének bemutatása a beszámoló típusa alapján a kiegészítő mellékletekben 
Egy vállalkozás megítélése szempontjából fontos tényező a vagyoni helyzet mellett a rövid és hosszú távú pénzügyi helyzete is, így a törvény előírja a pénzügyi helyzet, a likviditás és a fizetőképesség bemutatását, melynek értékei a 8. táblázatban találhatók. A vagyoni helyzethez, eszközök és források összetételéhez képest kedvezőbb képet mutatnak a viszonyszámok, hiszen a 8226 informatikai cég kicsivel több, mint fele (51\%) szerepeltette a kiegészítő mellékletében a pénzügyi helyzetet, míg a sportvállalkozások 43\%-a tette ezt közzé. Szintén az egyszerűsített éves beszámolót készítő vállalkozások aránya dominál, $42 \%$ és $36 \%$ a vizsgált cégeknek az, aki ilyen beszámolótípust készít és eleget tett a törvényi előírásoknak is.

\begin{tabular}{|c|c|c|c|c|}
\hline \multirow{3}{*}{ Beszámoló típus } & \multicolumn{4}{|c|}{ Pénzügyi helyzet } \\
\hline & \multicolumn{2}{|c|}{$\begin{array}{c}\text { Információ-technológiai } \\
\text { szolgáltatás }\end{array}$} & \multicolumn{2}{|c|}{ Sporttevékenység } \\
\hline & Nincsen & Van & Nincsen & Van \\
\hline Nem adott meg & $9 \%$ & $4 \%$ & $5 \%$ & $3 \%$ \\
\hline Egyszerűsített éves & $36 \%$ & $42 \%$ & $47 \%$ & $36 \%$ \\
\hline Éves beszámoló & $4 \%$ & $5 \%$ & $5 \%$ & $5 \%$ \\
\hline Összesen & $49 \%$ & $51 \%$ & $57 \%$ & $43 \%$ \\
\hline
\end{tabular}

8. táblázat: A pénzügyi helyzet bemutatása a beszámoló típusa alapján a kiegészító mellékletekben

A különféle gazdasági elemzések közül végül a jövedelmezőségi helyzet bemutatását írja elő kötelező tartalmi elemként a kiegészítő mellékletben, így a 9. táblázat a jövedelmezőség kifejezés előfordulásának gyakoriságát mutatja be. Érdekes, hogy a kért vagyoni, pénzügyi és jövedelmi helyzet értékelése közül a jövedelmezőség az, amit leginkább bemutattak a vizsgált cégek, hiszen az IT végek 56\%-a, míg a sportvállalkozások 45\%-a tartalmazta ezt. Az elemzett 8226 IT vállalat 4\%-a készített éves, 46\%-a egyszerúsített éves beszámolót és tett eleget a törvényi előírásnak, míg 5\%-ának pedig nem derült ki a beszámolótípusa a kiegészítő mellékletéből. Az 1616 sportvállalat közül 5\% éves, 37\% egyszerűsített éves beszámolót készített, míg 3\%-ának pedig nem ismert a beszámolótípusa a kiegészítő mellékletéből, viszont a jövedelmi helyzetük ott bemutatásra került.

\begin{tabular}{|c|c|c|c|c|}
\hline \multirow{3}{*}{ Beszámoló típus } & \multicolumn{4}{|c|}{ Jövedelmezőség } \\
\hline & \multicolumn{2}{|c|}{$\begin{array}{c}\text { Információ-technológiai } \\
\text { szolgáltatás }\end{array}$} & \multicolumn{2}{|c|}{ Sporttevékenység } \\
\hline & Nincsen & Van & Nincsen & Van \\
\hline Nem adott meg & $8 \%$ & $5 \%$ & $5 \%$ & $3 \%$ \\
\hline Egyszerűsített éves & $32 \%$ & $46 \%$ & $45 \%$ & $37 \%$ \\
\hline Éves beszámoló & $5 \%$ & $4 \%$ & $5 \%$ & $5 \%$ \\
\hline Összesen & $44 \%$ & $56 \%$ & $55 \%$ & $45 \%$ \\
\hline
\end{tabular}

9. táblázat: A jövedelmi helyzet bemutatása a beszámoló típusa alapján a kiegészítő mellékletekben

A 2000. évi C. törvény szerint a cash flow-kimutatás a beszámoló kiegészítő mellékletének része. Összeállításának követelményeit a 7. számú melléklet rögzíti, mely egykötelezően előírt szerkezeti felépítést, illetve az egyes kategóriák és bizonyos sorok tartalmát, magyarázatait, értelmezéseit tartalmazza. Magyarországon ennek a riportnak az elkészítése ésközzététele kizárólag az éves beszámolót, illetve az összevont/konszolidált éves beszámolót készítő vállalkozások számára kötelező [15]. A Kiegészítő melléklet részét képző Cash-flow kimutatást, amely a pénz be-és kiáramlását mutatja be a piaci szereplő számára a 8226 IT cégből mindössze 2,7\% mutatta be, míg az 1616 Sportvállalatból 
0,9\%-uk szerepeltette. Ez még nem lenne alapvetően probléma, hiszen az egyszerűsített éves beszámolót készítő vállalkozóknak nem kötelező tartalmi eleme, viszont az évesnek igen. A 738 éves beszámolót készítő IT cég mindössze 13,41\%-a, míg a 158 éves beszámolót készítő sportvállalat 4,43\%a tett eleget a kötelezettségének, mutatta be a Cash-flow kimutatást a kiegészítő melléklete részeként.

\begin{tabular}{|l|r|r|r|r|}
\hline \multirow{2}{*}{ Beszámoló típus } & \multicolumn{4}{|c|}{ Cash-flow kimutatás } \\
\cline { 2 - 5 } & \multicolumn{2}{|c|}{$\begin{array}{c}\text { Információ-technológiai } \\
\text { szolgáltatás }\end{array}$} & \multicolumn{2}{c|}{ Sporttevékenység } \\
\cline { 2 - 5 } & Nincsen & \multicolumn{1}{|c|}{ Van } & Nincsen & \multicolumn{1}{c|}{ Van } \\
\hline Nem adott meg & $12,7 \%$ & $0,2 \%$ & $7,7 \%$ & $0,0 \%$ \\
\hline Egyszerúsített éves & $76,8 \%$ & $1,3 \%$ & $82,0 \%$ & $0,5 \%$ \\
\hline Éves beszámoló & $7,8 \%$ & $1,2 \%$ & $9,3 \%$ & $0,4 \%$ \\
\hline Összesen & $\mathbf{9 7 , 3 \%}$ & $\mathbf{2 , 7 \%}$ & $\mathbf{9 9 , 1 \%}$ & $\mathbf{0 , 9 \%}$ \\
\hline
\end{tabular}

10. táblázat: A cash-flow kimutatás bemutatása a beszámoló típusa alapján a kiegészítő mellékletekben

\section{Következtetések}

A külső és belső piaci szereplők számára egyaránt nélkülözhetetlen, hogy rendelkezzenek a döntéshozatalhoz szükséges információkkal, melyet a mérleg és eredménykimutatás számszaki adatain túl leginkább a kiegészítő melléklet szöveges magyarázatai, információi, kiegészítései adnak. A kiegészítő melléklettel kapcsolatban számos kutatás foglalkozott már, miszerint nem minden esetben felel meg a törvényi előírásoknak, ezáltal a célját nem éri el. Összességében jelen kutatás is ezeket a kritikákat támasztja alá, ezáltal a döntéshozatal nem minden esetben kellően megalapozott, a kockázatot növeli. Fontos megjegyezni, hogy a kutatás során csak a kifejezésekre kerestem rá szövegbányászat segítségével, azok tartalmát külön nem vizsgáltam. Továbbá az általános, specifikus és tájékoztató rész kifejezés használata nem kötelező a törvényi előírások alapján csak hasznos az átláthatóság miatt, viszont azokkal kapcsolatos tartalmi elő́rások bemutatása már kötelező minden egyes éves beszámolót készítő vállalat számára. Összességében minden egyes kifejezést a vizsgált vállalatok kevesebb, mint fele mutatta be a kiegészítő mellékletében. A tagolással ellentétben a vagyoni, pénzügyi és jövedelmezőségi helyzet bemutatását kötelezően előírja a számviteli törvény, azon belül viszont mutatószámok alkalmazása a vállalatok sajátosságai alapján rájuk van bízva. Összességében a vagyoni helyzet kifejezést az IT cégek 39\%-a, a sportvállalkozások 30\%-a mutatta be, míg az eszközök és források összetételét már csak a 10-10\%-uk. A pénzügyi és jövedelmezőségi helyzetnél kedvezőbb képet kaptunk, körülbelül a cégek fele szerepeltette ezeket a mutatókat. Fontos megjegyezni, hogy a mutatószámok kiszámítása nem nyújt elegendő információt a döntéshozónak, azok mögöttes tartalmára és jelentős változásaira, azok okaira is érdemes és célszerű kitérni a magyarázatok során. Végül a Cashflow kimutatásra egyértelmű sémát nyújt a törvény az éves beszámolót készítő gazdálkodók számára, mégis az IT cégek 13\%-a, a sporttevékenységet folytatók 4\%-a tette ezt a kötelező elemet közzé.

\section{Köszönetnyilvánítás}

„Az Innovációs és Technológiai Minisztérium ÚNKP-19-3-1 kódszámú Új Nemzeti Kiválóság Programjának szakmai támogatásával készült." 


\section{Hivatkozások}

[1.] 2000. évi törvény a számvitelről https://uj.jogtar.hu/\#doc/db/1/id/A0000100.TV/ts/20161126/ Letöltés dátuma: 2020.01.03.

[2.] E. Böcskei, É. Kádasné V. Nagy (2014): A számviteli mutatószámoktól a Markov-láncok alkalmazhatóságáig, Controller Info 2014/4 pp. 2-8.

[3.] Z. Musinszki (2016): Pénzügyi mutatókon innen és túl ÉSZAK-MAGYARORSZÁGI STRATÉGIAI FÜZETEK 13:(2) pp. 71-80.

[4.] V. Fenyves, Z. Bács, Z. Zoltán, E. Böcskei, T. Tarnóczi (2018): THE ROLE OF THE NOTES TO THE FINANCIAL STATEMENTS IN CORPORATE DECISION-MAKING, CORPORATE OWNERSHIP AND CONTROL 15 : 4 pp. 138-148. , 11 p.

[5.] V. Fenyves, T. Tarnóczi (2019): Examination of the expectations of controllers on the labour market, CORPORATE OWNERSHIP AND CONTROL 17 : 1 pp. 60-70.

[6.] B. Bayaraa, T. Tarnóczi, V. Fenyves (2019): MEASURING PERFORMANCE BY INTEGRATING KMEDOIDS WITH DEA: MONGOLIAN CASE JOURNAL OF BUSINESS ECONOMICS AND MANAGEMENT $20: 6$ pp. 1238-1257.

[7.] V. Fenyves (2014): Vállalati teljesítményértékelés pénzügyi mutatók és a DEA felhasználásával, ACTA SCIENTIARUM SOCIALIUM 40 pp. 133-146.

[8.] K. Zsidó, P. Gróf (2015): Gazdasági (kereskedelmi) tevékenységek teljesítménymérése, Act Sci Soc 44 (2015): 111-118

[9.] C. Szigeti, Á. Szennay, J. Beke Lismányi Endréné, R. J, Polák-Weldon, L. Radácsi (2019): Vállalati ökológiailábnyom-számítás kihívásai a KKV-szektorban, VEZETÉSTUDOMÁNY / BUDAPEST MANAGEMENT REVIEW, L. ÉVF. 2019. 7-8. SZÁM/ ISSN 0133-0179 DOI: 10.14267

[10.] L. Kertész, Z. Zéman (2016): A cash flow módszertani megközelítése 2016/IV/4. Controller Info. Copy \& Consulting Kft. 33-37. o. ISSN 2063-9309

[11.] E. Böcskei, N. Sereg (2019): A Cash Flow kimutatás - A befektetési döntések nélkülözhetetlen információforrása, Economica X. Új évf., 3-4. sz. , ISSN 2560-2322

[12.] K. Máténé Bella, I. Ritzné Kazmir (2020): A multinacionális nagyvállalatok stratégiai döntéseinek hatása a termelés oldali GDP alakulására, Statisztikai Szemle 98. évfolyam 3. szám, pp. 212-241. DOI: 10.20311/stat2020.3.hu0212

[13.] F. Hamar (2019): Hogyan befolyásolta a 4. ipari forradalom a magyar telekommunkikációs szektor cégeinek pénzügyi helyzetét 2013-2017 között?, Multidiszciplináris kihívások, Sokszínű válaszok, Budapesti Gazdasági Egyetem, 2019. 2. szám, https://doi.org/10.33565/MKSV.2019.02.03 
[14.] E. Katits, É. Szalka, F. Nagy, T. Könczöl (2019): A magyar top cégek a turizmusban, avagy egy sikerre éhes ágazat pénzügyi diagnózisa, Multidiszciplináris kihívások, Sokszínű válaszok, Budapesti Gazdasági Egyetem, 2019. 2. szám, https://doi.org/10.33565/MKSV.2019.02.04

[15.] D. Droppa (2016): Cash flow-kimutatások: A hazai és nemzetközi előírások, E-conom V./1, 2016, DOI: 10.17836/EC.2016.1.135, pp 135-147. 